\title{
ASUPAN PURIN TERHADAP KADAR ASAM URAT PADA PENDERITA GOUT ARTHRITIS DI WILAYAH KERJA PUSKESMAS RANOTANA WERU
}

\author{
${ }^{1 a}$ Henry S. Imbar ${ }^{2}$ Nonce N, Legi ${ }^{3}$ Jualita Dorace Pinunsada, \\ ${ }_{123}$ Jursan Gizi Poltekkes Kemenkes Manado Idonesia \\ aemail korespondensi: hnrmbr@gmail.com
}

\begin{abstract}
Gout or gout is a chronic arthritis caused by swelling and usually attacks the big toe. Factors causing gout arthrits are excessive uric acid products, obesity, diabetes accompanied by high blood pressure, excessive protein consumption, sex, and alcohol. The purpose of this study was to determine the relationship between purine intake and uric acid levels in patients with gout arthritis in the Ranotana Weru Public Health Center.

The method used in this study uses a cross sectional design on a total of 44 samples. The sample criteria are patients with symptoms of gout arthritis and can communicate well. Research sites in the Ranotana Weru Public Health Center in Manado in 2018. Data on age, sex, and occupation can be obtained through interviews using the informed consent form. Purine intake data can be obtained through interviews with the Semi Food Frequency Questinary (FFQ). Gout criteria are divided into two, namely normal and high bivariate data analysis using the chi square test.

The results of research on patients with high uric acid levels are $73 \%$ and $27 \%$ normal, asupa purin more $68 \%, 21 \%$ enough and less $11 \%$. The conclusion from this study is that there is a chi square test relationship showing that intake of purines has a significant relationship between uric acid levels with a value of $p=0,000(p=0.05)$.
\end{abstract}

Keywords: Purine intake, Uric asid, Gout

\section{PENDAHULUAN}

Gout adalah salah satu penyakit arhtritis yang di sebabkan oleh metabolisme abnormal purin yang di tandai dengan meningkatnya kadar asam urat dalam darah. Gout Arthritis biasa dikenal dengan Asam Urat, karena penyakit Asam Urat berhubungan erat dengan dengan jenis rematik ini. Karena kedua penyakit ini saling berinteraksi satu sama lain, karena asam urat sering menyerang persendian dan uraturat halus dari sel-sel syaraf yang terhubung dengan tulang.

Asupan purin adalah salah satu senyawa yang dimetabolisme tubuh dan hasil akhir menjadi asam urat. Bahan makanan yang mengandung asupan purin tinggi dapat memberikan dampak terjadi peningkatan kadar asam urat dalam darah. Untuk mencegah tidak terjadi peningkatan asam urat maka disarankan untuk mengkonsumsi makanan yang mengandung asupan purin rendah (nasi, roti, macaroni, mie, crakers, susu, keju, telur, sayur yang tidak berwarna hijau dan buah-buahan). Jika konsumsi asupan purin $>100 \mathrm{~g} /$ hari maka dikatakan tinggi, konsumsi asupan purin antara 50-100 $\mathrm{g} / \mathrm{hr}$ makan dikatakan normal, dan konsumsi asupan purin $<50 \mathrm{~g} / \mathrm{hr}$ makan dikatakan kurang.

Berdasarkan data Riskesdas Indonesia tahun 2013, prevalensi penyakit sendi yang terdioagnosa oleh dokter adalah $11,9 \%$ dan di diagnosa oleh tenaga kesehatan $24,7 \%$, berdasarkan data Riskesdas Sulawesi Utara penyakit sendi terdiagnosa oleh dokter 
adalah 10,3\% dan yang terdiagnosa tenaga kesehatan sekitar 19,1\%. Sedangkan pada kota manado memiliki prevalensi terhadap asam urat yaitu 14,2\%. Menurut survey " (NHANES) di Asia prevalensia penderita gout arthritis di usia di atas 20 tahun sebesar $24 \%$, usia $50-60$ tahun sebesar $30 \%$, usia lebih dari 60 tahun sebesar $40 \%$ (Lingga,2012).

Tujuan penelitian ini untuk mengetahui hubungan asupan purin terhadap kadar asam urat pada penderita gout arthritis di Wilayah Kerja Puskesmas Ranotana Weru.

\section{METODE}

Penelitian ini merupakan penelitian jenis cross sectional. Penelitian ini dilakukan pada bulan Juni sampai dengan Juli tahun 2018. Tempat penelitian di Puskesmas Ranotana Weru. Populasi penelitian ini adalah semua penderita gout arthritis yang datang berobat di Puskesmas Ranotana Weru. Jumlah sampel pada Penelitian ini berjumlah 44 orang dengan menggunakan teknik pengambilan sampel purposive sampling dan harus memenuhi kriteria sampel sampai jumlah terpenuhi. Kadar asam urat di lihat dari hasil cek dengan menggunakan Autocek oleh tenaga laboratorium medis. Untuk mengetahui asupan purin responden deperoleh dengan wawancara mengunakan formulir semi food frequency questionary (semi- FFQ).

Analisis data mengunakan analisis univariat dan bivariate. Analisis univariat dilakukan untuk manyajikan data usia, jenis kelamin, pekerjaan, asupan Purin dan kadar Asam Urat. Analisis bivariat untuk melihat hubungan variabel terikat (dependent) yaitu kadar Asam Urat dan variabel bebas (independent) yaitu asupan Purin. Analisis bivariate menggunakan Uji Chi kuadrat.

\section{HASIL}

\section{A. Karakteristik Responden}

Hasil penelitian ini menunjukkan bahwa dari 44 responden, sebagian besar responden berjenis kelamin perempuan dengan jumlah 44 orang (55\%) dan laki- laki 20 orang (45\%). Umu responden terbanyak yaitu kelompok umur $48-51$ tahun $(50.2 \%)$. Jenis pekerjaan terbanyak yaitu IRT berjumlah 15 orang (35.3\%) dan terendah petani de. ngan jumlah 4 orang (4.2\%).

\section{B. Deskripsi Kadar Asam Urat}

Hasil penelitian ini menunjukkan bahwa dari 44 responden, sebagian responden dengan kadar asam urat tinggi berjumlah 30 (68\%) responden dan kadar asam urat normal 14 orang (32\%).

\section{Deskripsi Asupan Purin}

Hasil penelitian ini menunjukkan bahwa bahwa dari 44 responden dalam penelitian sebagian besar responden mengkonsumsi bahan makanan yang mengandung asupan purin yang lebih yaitu 30 responden (68\%). Bahan makan yang mengandung asupan purin tinggi yang sering dikonsumsi responden yaitu usus, jeroan, daging sapi, limpa, udang, ikan tuna, ikan sarden, daging ayam, tahu, tempe, sayur kangkung, daun singkong. 


\section{Hubungan Asupan Purin dengan Kadar Asam Urat}

Hasil penelitian ini menunjukkan bahwa sebagian besar responden mengkonsumsi bahan makan sumber purin lebih dan memilik kadar asam urat tinggi yaitu 20 responden (83.3\%). Hasil analisisi statistik menunjukkan bahwa ada hubungan yang signifikan antara asupan purin dengan kadar asam urat $(\mathrm{p}=0,000)$

\section{PEMBAHASAN}

Perempuan memiliki resiko lebih rendah menderita Gout Arthritis, karena perempuan memiliki hormon esterogen yang berfungsi sebagai uricosuric agent, yaitu suatu bahan kimia yang berfungsi membantu proses ekskresi asam urat melalui ginjal. Dalam penelitian Setyoningsi (2009) ditemukan bahwa responden yang paling banyak berjenis kelamin laki-laki yaitu $24(80 \%)$ responden. Menunjukan ada hubungan yang bermakna antara jenis kelamin deng resiko Gout Arthritis. Sejalan dengan penelitian Untari dkk (2017), menyatakan bahwa penderita Gout Arthritis lebih banyak di temukan pada laki-laki yaitu sebanyak $10(71,4 \%)$ di bandikan pada perempuan $(28,6 \%)$.

Usia subjek pada peneltian ini sebagian besar lebih dari 40 tahun. Karena seperti kita ketahui bahwa semakin bertambahnya umur maka akan terjadi perubahan fungsi dari setiap organ terutama gangguan pada organ ginjal. Sehingga umur merupakan salah satu resiko terjadinya Gout arthritis. Hal ini sesuai dengan penelitian Kartia (2009), menyatakan bahwa umur diatas 40 tahun rentan terkena penyakit asam urat, karena umur yang semakin mendekati lanjut usia metabolisme tubuh akan menurun dan menyebabkan peningkatan kadar asam urat. Jenis pekerajaan berkaitan erat dengan Gout arthritis. Menurut Nengsi dkk (2014), menyatakan bahwa dari 66 responden lebih banyak responden pekerjaan sebagai ibu rumah tangga sebanyak $40(40,4 \%)$ responden dan paling sedikit sebagai pedagang sebanyak $5(51,1 \%)$ responden. Sehingga tidak ada hubungan antara jenis pekerjaan dengan kadar asam urat.

Asam urat merupakan metabolisme akhir purin. Lina dan Setyoningsi (2014), jika kadar asam urat dalam berlebihan akan menimbulkan penumpukan Kristal asam urat dalam darah. Bila terbentuk dalam sendi makan akan tebentuk menjadi gout (asam urat) dan lebih parahnya jika terjadi pada penimbinan pada ginjal tidak menutup kemungkinan akan menumpk menjadi batu ginjal. Purin merupakan satu senyawa di metabolisme di dalam tubuh dan menghasilkan produk akhir yaitu asam urat. Dalam penelitian Diantari \& Candra (2012), menyatakan bahwa makanan yang mengandung zat purin dapat meningkatkan asam urat dalam darah.

Suiraoka (2012), menyatakan bahwa purin merupakan salah satu senyawa metabolisme di dalam tubuh yang menghasilkan produk akhir yaitu asam urat. Jenis makanan yang kaya purin biasanya makanan bersumber protein hewani seperti daging sapi, seafood, kambing, kacang-kacangan, jamur, dan kembang kol.

Setelah dilakukannya analisis data dengan menggunakan uji chi kuadrat dapat diperoleh tingkat signifikan $p=0,000$ yang menunjukan nilai $p=<0,05$. Dari nilai terseut menunjukan bahwa $\mathrm{HO}$ ditolak berarti ada hubungan yang signifikan antara asupan purin dengan kadar asam urat pada penderita gout arthritis di Wilayah kerja Puskesmas Ranotana Weru. Hasil penelitian ni sejalan dengan penelitian Silviani dkk (2014), dimana menggunkan uju korelasi Rank Spearmen menghasilkan $p=0,038$ $(p=<0,05)$ yang menyatakan ada hubungan yang bermakna antara Asupan Purin 
dengan kada Asam Urat. Asupan purin memberikan kontribusi terhadap tubuh dimana konsumsi bahan makanan purin tinggi maka akan meninkatkan kadar asam urat dalam darah. Peryataan ini juga di dukung oleh penelitian Hensen dkk (2007), menyatakan bahwa makanan tinggi purin dikatakan dapat mempengaruhi meningatnya kadar asam urat, dengan membatasi konsumsi asupan purin maka akan dapat mencegah atau dapat menurunkan kadar asam urat dalam darah. Pada penelitian Diantari \& Candra (2013), terdapat hubungan antara asupan purin dengan kadar asam urat yang telah dilakukan pada 40 responden dengan kadar asam urat normal $(92,5 \%)$ dan Mengkonsumsi asupan purin normal (82,5\%).

\section{KESIMPULAN}

Responden sebagian besar mengkonsumsi asupan purin tinggi diabndingkan dengan konsumsi cukup dan kurang dan memiliki kadar asam urat tinggi lebih dibandingkan dengan dan kadar asam urat normal. Terdapat hubungan yang bermakna antara asupan purin dengan kadar asam. Saran bagi instansi terkait yaitu Puskesma Ranotana Weru, dapat membantu memberikan informasi dan juga pemahaman tentang bahan makanan yang baik pada penderita gout arthritis terutama bahan makanan yang mengandung asupan purin rendah untuk mencegah terjadi peningkatan asam urat.

\section{DAFTAR PUSTAKA}

Balitbang. (2013), Riset Kesehatan Dasar Sulawesi Utara. Manado Balitbankes, (2013). Riset Kesehatan Dasar Indonesia. Jakarta

Diantari, E \& Candra, A. (2013). Pengaruh Asupan Purin dan Cairan Terhadap Kadar Asam Urat Wanita Usia 50-60 Tahun di Kecamatan Gajah Mungkur,Semarang. Jurnal of Nutrition College. 2 (1:44-49)

Hensen, Putra T,R. (2007). Hubungan Konsumsi Purin Dengan Hperurisemia Pada Suku Bali Di Daerah Pariwisata Pedesaan. Artikel Asli ilmu Penyakit Dalam FK Unud RS Sanglah. Halaman 37-43

Kartia N, (2009). Asam Urat Benarkah Hanya menyerang laki-laki. Mizan Media Utama. Yokyakarta

Lina, N. \& Setiyono, A. (2014). Analisis Kebiasaan Makan yang Menyebabkan Peningkatan Kadar Asam Urat. Jurnal Kesehatan Komunitas Indonesia. 10 (2: 1004-1016)

Lingga L. (2012), Bebas Penyakit Asam Urat Tanpa Obat. PT Agromedia Pustaka.Jakarta

Nengsi S,W. Bahara, B \& Salam,A. (2014). Gambaran Asupan Purin, Penyakit Arthritis Gout, Kualitas Hidup Lanjut Usia Di Kecamatan Tamalanrea. Jurnal Fakultas Kesehatan Masyarakat. Halaman 9

Setyoningsis, R, (2009). Faktor-faktor yang berhubungan dengan kejadian hiperurisemia pada pasien rawat jalan RSUP Dr. kariadi semarang. Semarang.

Silvana, H. Bintanah, S \& Isworo, J, T. (2014). Hubungan Status Gizi, asupan Bahan Makanan Sumber Purin Dengan Kadar Asamu Urat Pada Pasien Hiperurisemia Rawat Jalan di Rumah Sakit Tugurejo Semarang. Jurnal fakultas ilmu keperawatan dan kesehtan muhamadiayah semarang. Halaman 29-35.

Suiraoka, IP. (2012). Penyakit Degeneratif. Nuha Medika. Yokyakarta.

Untari I, Sarifah S, \& Sulastri. Hubungan Antara Penyakit Gout Dengan Jenis Kelamin dan Umur Pada Lansia. Jurnal Universitas Muhammadiyah Magelang. 6 ( 267- 272). 